Hvad er islams syn på kommunisme, på onani, på gevinstopsparing, eller organdonation? Hvis en lægmand ønsker svar på sådan et spørgsmål, kan han eller hun henvende sig til en muslimsk lærd, der så har pligt til at svare eller henvise videre. Et sådant svar kaldes en fatwa, det at give fatwaer kaldes futya eller ifta, og den der giver en fatwa kaldes en mufti.

\title{
FATWAERNES GENKOMST
}


TEKST: Jakob Skovgaard-Petersen

IFØLGE ISLAMISK TRADITION blev de første fatwaer givet af profeten Muhammad selv for fjorten århundreder siden til de første troende, som måtte have mange ting ved den nye tro forklaret. Og så læange der er ukyndige muslimer til, vil de fortsæte med at bede deres mere lærde trosfæller om fatwaer om alskens emner: hvordan skal jeg bede, når jeg er blevet lam $\mathrm{i}$ venstre side, hvad er reglerne for soning af brud på fasten, eller er det tilladt at arbejde som ølkusk, hvis man ikke drikker noget selv? I dag foregår det ikke mindst i ugeblade eller på internettet, også på norsk, dansk eller engelsk, for eksempel på siden www.islamonline.net.

\section{Hvad er nyt?}

Disse nye fatwaer adskiller sig fra tidligere tiders fatwaer derved, at muftien aldrig møder den, der spørger ham. Det vil sige, at konteksten er væk. Muftien kan ikke tage individuelle hensyn, han kan dårligt indtænke en social sammenhæng. I stedet må han tænke i principper; han må give fatwaen, så i princippet alle muslimer kan følge det overalt. Når en fatwa bliver masseproduceret i aviser, i radio, på Tv eller internet, må han endvidere regne med, at brugere vil anvende det til deres specifikke formål, og særligt interesserede vil sammenligne fatwaen med andre og kritisere den. Dette styrker en standardiserende, kontekstløs skripturalisme, hvor muftien ikke vil risikere for meget, men citere et klassisk princip. Sådan har det ikke altid været.

En anden forskel fra tidligere tider, at fatwaer i dag ikke spiller nogen rolle i retssystemerne. Tidligere kunne en sagsøger væbne sig med en fatwa for at underbygge sin sag over for dommeren, som også selv kunne finde på at udbede sig en fatwa, hvis det var en sæligt usædvanlig sag, der ikke var dæakket i retslitteraturen. De moderne muslimske stater har derimod en kodificeret statslov, som dommeren skal dømme efter, og han skal ikke selv søge i den addre retslitteratur. Dommere i den muslimske verden skal som andre steder i verden applicere en kodificeret lov, og de skal samle sig om en prøvelse af sagen og dens dokumenter. Sådan var det ikke i den førmoderne islamiske retstradition; her var ingen kodificeret lov, dommeren skulle selv udfinde retten ved hjælp af de metoder han havde lært i det religiøse retskollegium, madrasaen. Sagsøgere og anklagede måtte affinde sig med, at de ikke på nogen måde kunne gå ham i bedene; loven var ikke offentlig. Det bedste de kunne gøre var at komme med en fatwa af en endnu større 
lærd, som de mente understøttede deres synspunkter. Navnlig i Det osmanniske rige udviklede dette behov for fatwaer $\mathrm{i}$ domstolene sig til en veritabel industri, hvor den allerøverste mufti i Istanbul, kaldet Shaykh al-Islam, gav hundredvis af fatwaer hver dag til folk, der skulle bruge dem i domstolene. Dette kunne kun lade sig gøre ved, at sekretærer skrev fatwaerne om, så han alene skulle tage stilling til et princip, som helst skulle kunne besvares med et ja eller nej. En tydelig bevægelse, altså, i retning af det standardiserde, ikkekontekstuelle fatwa. Men også Det osmanniske rige gik gradvist vak fra systemet med dommerens retfinding og mod kodificeret lov.

I dag er det alene i Saudi-Arabien, hvis retssystem er tættere på klassisk islamisk retspraksis end andre landes, at fatwaer kan fremføres i retssager. Dette sker dog mest på den måde, at de øverste lærde, og sæligt en lille håndfuld enkeltpersoner gennem moderne saudisk historie, har udstedt fatwaer om relevante emner, som så får en grad af retsvirkende karakter i domstolene. Det er altså ikke helt en "argument-industri” for almindelige mennesker på linie med den osmanniske.

\section{Fatwaer imod staten}

Den nye mere anonyme og retligt uforpligtende karakter har vist sig at være fatwaernes styrke. Hvor mange andre klassiske islamiske teologiske og juridiske genrer har haft vanskeligt ved at forny sig, har behovet for at spørge om fatwaer aldrig været større, måske netop fordi folk forsøger at leve et moralsk og islamisk liv på mange områder, som retssystemerne i dag ikke tager sig af. Endelig har navnlig politisk aktive muslimske lærde taget fat- waerne til sig. Dels fordi de er stærkt optaget af at kommunikere deres budskaber ud til bredere befolkningsgrupper, men dels også fordi det gør det vanskeligt for staterne at lukke munden på dem. For det at udstede fatwaer er en del af deres arbejde, og det udstiller staten som en fjende af religionen, hvis den forfølger en lærd på det grundlag.

Staterne har imidlertid selv gået foran i den politiske anvendelse af fatwaer. De fleste muslimske stater har en statsmufti,

\section{Det siger sig selv at staten har stoerke forventninger til hva en statsmufti skal mene.}

som udsteder fatwaer til administrationen og bidrager til at give lovgivning og administration islamisk legitimitet. Det siger sig selv, at staten undertider har stæke forventninger til, hvad en sådan statsmufti skal mene, og anklagen om at være regimets islamiske figenblad hænger ofte i luften. Statsmufti-embederne bliver typisk oprettet samtidigt med, at de moderne stater opretter lovgivende forsamlinger eller $\mathrm{i}$ alt fald går over til kodificeret lov - og dermed netop forlader den traditionelle retsbasis i de klassiske islamiske retsskolers curricula.

Statsmuftien skal overordnet sikre, at statens administration og love lever op til en - typisk modernistisk - tolkning af islam, så det er staten der konsulterer ham. Jærne almindelige mennesker kan som oftest også godt skrive til ham og anmode om en fatwa, men den vil så have gyldighed for dem privat (hvis de vædger det), men 
ikke i retssystemet. Det kan de finde på at gøre, fordi det ofte vil være både hurtigere og billigere end at køre en sag gennem domstolene.

I nogle muslimske lande, hvor dele af befolkningen er utilfreds med den statslige lovgivning, kan enkeltpersoner endvidere konsultere muftier og følge deres fatwaer og vejledning netop som alternativ til det statslige retssystem. Simpelthen fordi de regner statens lov for uislamisk og illegitim.

Muslimer med en sådan forståelse af staten vil dog sjæadent henvende sig til lige præcis statsmuftien for at få vejledning, men netop holde sig til mere oppositionelle muftier, som deler deres syn på statens illegitimitet. Et sigende eksempel er spørgsmålet om observeringen af nymånen, som markerer begyndelsen på den nye måned. Dette er særligt vigtigt ved indledningen og afslutningen på ramadan, fordi muslimerne skal vide, om de skal faste eller ej. I en rakke lande er det statsmuftiens opgave at proklamere, om månen er blevet set, sådan at det kan annonceres i radio og tv, og de troende påbegynde eller afslutte fasten. Men dette samspil mellem stat, medier og mufti om public service for de muslimske befolkning er jo en symbolsk markering af statens islamiske identitet. Derfor ser man fra tid til anden, at radikale grupper beslutter netop ikke at begynde fasten på den dag, som statsmuftien proklamerer for at undgå en implicit anerkendelse af statens religiøse dignitar.

Så flyver der frem og tilbage med fatwaer om, hvordan månen skal observeres, og hvordan det skal annonceres. Men at fatwaer kan anvendes som redskaber til at positionere sig selv som islamisk autoritet, behøver vist få mennesker i dag at blive mindet om.

\section{Kollektive fatwaer}

En sidste vigtig udvikling inden for de seneste 50 år er tendensen til at organisere store lærde, for eksempel delegerede fra forskellige muslimske lande, til at træde sammen og debattere nye fænomener som hjernedødskriterier eller kunstig befrugtning. Ved kollektivt at tage stilling og udstede en fælles fatwa håber de, at den så bliver taget som vejledende af såvel læge muslimer som statslige administrationer rundt omkring i verden. Igen er det sæligt SaudiArabien, der har været aktiv i at organisere denne kollektive fatwa-virksomhed, sæligt gennem den internationale organisation Den muslimske verdensliga, som de sponsorerer. Men saudernes massive forsøg på at eksportere deres egen puritanske version af islamisk lov møder forventeligt modstand i de samfund og miljøer, hvor sauderne er upopulære. Derfor er der også vokset en konkurrence frem mellem kollektive fatwa-udstedende organer.

Vigtigt er det derfor at forstå, at fatwaer ikke er udtalt "ex catedra", som uimodstøelige bud, som man skal følge, hvis man overhovedet kan kaldes muslim. Om snart sagt ethvert emne, vil der være fatwaer, som er i modstrid med hinanden. Dette er et vasentligt problem for muslimerne overalt i verden. Men det gør også, at vi skal tage fatwaer som det, de er: pressemeddelelser fra muslimske lærde, og ikke love eller bud, som samtlige muslimer nu er forpligtet til at effektuere. Dette gadder ligefuldt for Ayatollah Khomeinis berygtede fatwa fra 1989 , der opfordrede alle verdens muslimer til mord på Salman Rushdie. Mange muslimer i verden var frastødt af denne util- 
slørede opfordring til mord. Men andre var helt på linie med Khomeini, som faktisk dannede mode: Mange radikale muslimer - også sunni-muslimer som den militante Umar Abd al-Rahman, fængslet i usA, har i de mellemliggende I4 år hyppigt refereret til Khomeinis fatwa i tilsvarende fordømmelser mod forfattere og intellektuelle, de ville af med. Enkelte, som den ægyptiske debattør Farag Foda, er faktisk blevet myrdet kort tid efter, at sådanne fatwaer var blevet udstedt.

Man kan valge at sige, at disse lærde og politikere optræder uislamisk og uden hjemmel i islamisk lov, og det er der bestemt også mange muslimer der vil mene. De vil påvise, hvordan klassisk islamisk jura i sådanne tilfædde har visse retsgarantier, herunder retten til at angre. Men mange andre muslimer har åbenbart ingen forbehold over for brugen af begrebet fatwa på den måde. Så for resten af verden er der vel ikke andet at gøre end at konstatere, at begrebet fatwa i dag også bliver anvendt $\mathrm{i}$ betydningen opfordring til mord. Og så naturligvis protestere og aktivt bekæmpe en sådan intimidering som det, den er: en kriminel handling og en grov knægtelse af ytringsfriheden.

Alligevel kan det være væsentligt at holde sig for øje, at fatwaer ikke er bandbuller, men retsinformation, og at der daglig i den islamiske verden udstedes tusindvis af store og små fredelige fatwaer om skilsmisse, arv, opdragelse og bønnestillinger. For det er uklogt at tillægge islamiske begreber en militant dimension, som de ikke har i sig selv. Vi må være i stand til at sondre mellem religiøst-politisk anvendelse af den islamiske traditions begreber og institutioner, og så disse institutioner som de forstås af andre muslimer. Ikke fordi de militante muslimer nødvendigvis har uret og ikke-militante muslimer har ret. Men fordi det heller ikke nødvendigvis er omvendt. Vi skal udforske, studere og forholde os til muslimer ud fra hvad de siger og gør, uden at privilegere nogle som de islamisk rigtige. Hvis vi i overskrifter og politisk jargon gør fatwaer synonymt med dødsdomme, har vi forbrudt os mod dette princip - og det tilmed for at bekræfte de mest militante muslimer i deres verdensog islamsyn. 